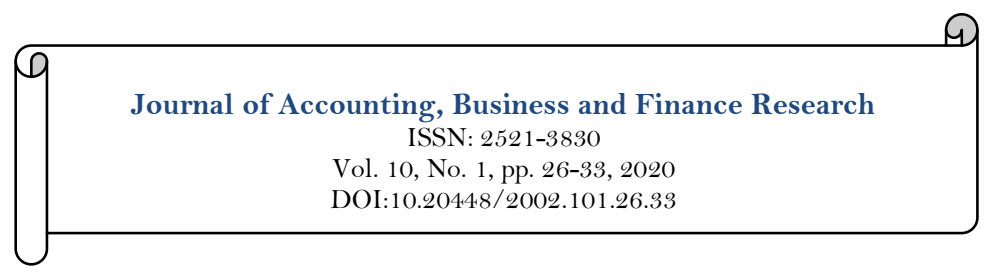

\title{
Role of Financial Development in Economic Globalization: Evidence from Six Developing Countries
}

Farah Amir

Western Carolina University, USA.

Email:farah.amir1987@gmail.com

\begin{tabular}{|c|c|}
\hline Abstract & \\
\hline $\begin{array}{l}\text { Among different dimensions of globalization, economic globalization is one } \\
\text { of the dimensions which involve the increased independence of different } \\
\text { economies of the world that comes from the enhanced trade across the } \\
\text { borders, transfer of international capital across the countries and through the } \\
\text { increases exchange of technologies. This concept is especially important for } \\
\text { the developing countries as they are in the process of establishment and } \\
\text { globalization. The current study associates this concept with the financial } \\
\text { development (FD) and the objective of the study is to investigate the impact } \\
\text { of FD on the economic globalization (EG) in the developing countries. In } \\
\text { this regard, the data has collected from the developing countries which } \\
\text { include Romania, Jordan, Mauritius, Oman, Poland and Somalia. The } \\
\text { data has been collected from the website of World Development Indicators by } \\
\text { the World Bank for the time period of } 27 \text { years. After data collection, the } \\
\text { researcher used different techniques and tools such as unit root test cross } \\
\text { sectional dependence and correlation test, Granger Casualty test etc. and the } \\
\text { desired results were obtained. The results of the current study have indicated } \\
\text { that the both dimensions of financial development i.e. gross domestic savings } \\
\text { and private credit has favourable impact on EG. In addition, the influence } \\
\text { of the two control variables i.e. GDP and FDI has also been found as } \\
\text { significant and positive. This study has the implications for the developing } \\
\text { countries as they can get assistance in many aspects with the objective to } \\
\text { increase globalization. }\end{array}$ & $\begin{array}{l}\text { Keywords: } \\
\text { Financial development } \\
\text { Economic globalization } \\
\text { Developing countries } \\
\text { Domestic savings } \\
\text { Private credit. } \\
\text { Licensed: } \\
\text { This work is licensed under a } \\
\text { Creative Commons Attribution } 4.0 \\
\text { License. } \\
\text { Publisher: } \\
\text { Scientific Publishing Institute } \\
\text { Received: } 11 \text { May } 2020 \\
\text { Revised: } 18 \text { June } 2020 \\
\text { Accepted: } 7 \text { July } 2020 \\
\text { Published: } 29 \text { July } 2020\end{array}$ \\
\hline
\end{tabular}

Funding: This study received no specific financial support.

Competing Interests: The author declares that there are no conflicts of interests regarding the publication of this paper.

\section{Background of the Study}

Globalization has sparked a revolution in the communication and information technology that results in boosting the arrival of an advanced level of global interconnectedness in the productive contribution of financial institutions. This globalization results in the enhancement of GDP and the foreign direct investment of a country and maintains the company's future. The problem statement of the present study is to inspect the significant impact of gross domestic saving (GDS) and credit to private sector based FD on the economic globalization of the developing states by specifically considering the influencing factors of FDI and GDP within the state. The overall research objectives of the paper are given as follows: critically inspect the impact of financial development on the economic globalization of a developing state; critically evaluate the impact of credit to the private sector on EG of a developing state; critically evaluate the influence of GDS on the economic globalization of a developing state, and critically consider the importance of foreign direct investment and GDP to globalize the state's economy. 
In the previous researches, the scholars worked on considering the global panel-based experiment on considering the financial development on economic development (Katircioğlu \& Zabolotnov, 2020). In addition to this, there was also worked on considering the large scale emerging economy by focusing on either globalization is detrimental to the financial development or (Shahbaz, Mallick, Mahalik, \& Hammoudeh, 2018) the role of agriculture value-added, in the aftermath of Paris Climate Agreement (COP21) (Wang, Vo, Shahbaz, \& Ak, 2020) and creating a dynamic linkage between the financial development, globalization, and carbon emission by considering the Asia Pacific Economic Cooperation countries (Zaidi, Zafar, Shahbaz, \& Hou, 2019). But this paper covers the gap of these previous articles by majorly focus on considering the gross domestic saving and credit to private sector based financial factors and their influence on the developing state's economic globalization.

This research will be an informative and attractive study in front of the Asian developing states and its government authorities to develop such economic policies that directly result in their economic globalization. Also, this valid data will help the financial advisers, banking sectors, and the related financial bodies to understand how the credit to the private sector (PS) and the GDS can cause a major impact on the overall EG of a state. Also, the related field economist, analyst and researchers can utilize this information in their data evaluation mechanism. After completing this section 1 of introduction, the next section will be based on a literature review where all the previous researchers' point of view and analysis on the selected variables will be discussed. In section 3, research methodology, there will be a brief discussion on the research method and applied testing mechanism. After this, section 4 will be based on results and analysis where all the statistical test based outcomes are interpreted. The last one is discussion and conclusion where all the outcomes are summarized in a paragraph form. Also, the limitations and future implications will be discussed in this section.

\subsection{Hypotheses Development}

A globalization theory is somehow related to internationalization which refers to growing the interdependence and interconnectedness concept throughout the world. This process-oriented theory was developed by Roland Robertson who considered it as an accelerated compression of the contemporary world and also intensified the consciousness of the world as a single entity (Barrow \& Keck, 2017). Such type of globalization comes to expose the complexities of the interconnectedness. In the previous researches, scholars used this theoretical approach to understand the influence of local domestic activities on a worldwide scale (Hay., 2016). This economic theory is considered by the business community of the developing states in order to expend their operating activities from one state to another state. Like Priyaranjan (Jha \& Gozgor, 2019) majorly considered this theoretical approach in addressing the relationship between globalization and taxation. They utilized such a model to capture the efficiency and compensation of globalization, and also predicted the two alternative modes of globalization named as financial openness and trade liberalization (Jha \& Gozgor, 2019).

\subsection{Financial Development and Economic Globalization}

In order to explain the influence of FD on the EG of a state, research was made by Katircioğlu \& Zabolotnov who demonstrated that there is a direct link between the financial instruments' development and the EG of a developed and developing state. The reason is that these factors are interlinked with one another in their operating activities like if the financial institutions actively performed in their loaning, investment and transaction-related activities then a cash-flow within a state becomes enhanced (Katircioğlu \& Zabolotnov, 2020). Also in the Environmental Science and Pollution research, the researchers stated that energy strategy is an essential ingredient to achieve the rapid development process of a state (Tariq, Xu, Muhammad, \& Alam, 2019). In the current year 2020, PredeeptaSethi and others studied the impact of FD, globalization, EG and the energy consumption (EC) on environmental sustainability in the Indian state. Also, the banking sector based development is adversely affecting environmental sustainability through the economic growth channel. According to them, the greener and cleaner technologies in the sustainable environment area are encouraged by proactive policies of a state (Sethi, Chakrabarti, \& Bhattacharjee, 2020). Well, in the Journal of Cleaner Production, the researchers stated that there is a dynamic linkage between FD, globalization and the carbon emission. According to their Westerlund Cointegration approach based statistical outcomes, financial development and globalization directly reduces the carbon dioxide release in both short run and long run. According to these scholars, there is a need to make some effective policies to improve the green energy (GE) and enhanced the technology usage (Zaidi et al., 2019). Similar to this, another related outcome was generated by Le Hoang Phong in their international journal where they specifically considered the ASEAN states in their economic openness, trade liberalization and the globalization based encouragement and concluded that both financial development and globalization directly increased the incremental energy demand. In the end, they concluded that globalization is an aggregate measure to significantly enhanced the $\mathrm{CO} 2$ emission and its impact on the economic globalization facet; also the energy consumption, financial development and urbanization directly boost the $\mathrm{CO} 2$ emission (Phong, 2019). After considering the previous literature, the following hypothesis has been suggested;

H1: There is a positive relationship between Financial Development and Economic Globalization. 


\subsection{Credit to Private Sector and Economic Globalization}

In the International Review of Economics \& Finance, Ghosh (2017) adopted different frequentist methods and the Bayesian analysis to justify the banking sector's globalization impact on the EG. According to them, the foreign banks directly face the informational bottlenecks that overcome them from lending to a maximum potential client-base in the host markets. The globalization of the Chinese development finance is contrasted with Western development finance. This shows that if the financial institution becomes empowered by the state then they will actively participate in the economic growth of a state (Chin \& Gallagher, 2019). This point of view was also justified by Peter Eppinger and NiklasPotrafke in their research article where they stated that globalization directly influenced the credit market deregulation. They stated that credit market deregulation is usually measured by the credit market freedom indicators. While their panel and cross-sectional regressions show that there is a positive correlation between the credit market deregulation (CMD) and globalization. Their two-stage least squares estimate that globalization had a casual effect on the CMD (Eppinger \& Potrafke, 2016). In the Journal of Financial Economic Policy, the business scholars majorly studied the impact of institutional quality (IQ) and globalization on the economic performance of the Indian economy by generating an active FD. However, the IQ does not impact on the short-run EG (Sehrawat \& Giri, 2019). After critically the previous research analysis on the credit to the PS and the EG, the following hypothesis has been suggested;

H2: There is a favorable relationship between Credit to Private Sector and Economic Globalization.

\subsection{Gross Domestic Saving and Economic Globalization}

Well, in order to explore the economic globalization concept in the gross saving perspective, many researchers explored their point of view by stated that such type of saving factor causes a direct impact on the overall sustainable EG of a state. It has stated that there is a direct nexus between EG and the three major indices for product diversification (named as intensive margin, extensive margin and Theil index) that result in the economic growth of a state (Gözgör \& Can, 2017). According to Coulibaly, Erbao, and Mekongcho (2018) the BRICS nations are growing faster than the developed nations between the 2002 and 2013. According to them, the EG and the entrepreneurship enhanced the development and growth, and the vibrant SMEs directly shift from the efficiency-driven to the innovation-driven developments. They stated that the factor mobility directly promotes the growth of investment and technology among the BRICS nations. In the end, they concluded that financing south-south trade and the multilateral alliance directly enhanced the global competition (Coulibaly et al., 2018). In addition, the other related field scholars also justified this related argument that economic globalization is one of the major factors for the company's sustainability and is highly affected by the gross domestic saving based economic activities. According to these scholars, there is a diverse short run and long run impact on the saving factor of economic growth. Their Augmented dickyoFuller (ADF) test stated that there is a long run significant relationship between gross domestic product and the economic globalization variable (Chorn \& Siek, 2017; Hossain, Kibria, \& Islam, 2018). Hence, after critically evaluate the previous research articles related to GDS and the EG, the following hypothesis has been proposed;

H3: There is a significant relationship between Gross Domestic Saving and Economic Globalization.

\section{Research Methodology}

The purpose to conduct the current effort is to identify the influence that is casted by FD on the EG in the developing regions of the globe. In this regard, the researcher has collected data from the developing countries which include Romania, Jordan, Mauritius, Oman, Poland and Somalia. The data has been collected from the website of World Development Indicators by the World Bank. This data is regarding the two dimensions of financial development i.e. private credit and gross domestic saving. In addition, the data about economic globalization has also been taken through the globalization index. Moreover, two control variables have also been included in this study i.e. GDP to measure EG and FDI. The data regarding all the aforementioned variables has been taken for the time period of 27 years regarding the aforementioned developing countries.

\subsection{Theoretical Framework}

As discussed earlier, the current study involves the checking of impact casted by credit to PS and GDS on the EG in domestic countries along with the two control variables, GDP and FDI, therefore, based on these variables the fowling function can be developed;

$E G=f(P C, G P S, G D P, F D I)$

In this function, EG represents the economic globalization, PC represents private credit, GDS shows GDS, GDP denotes gross domestic product and finally FDI indicates foreign direct investment. The natural $\log$ of all these variables has been taken and an augmented multivariate production function can be developed as presented below;

$$
\ln E G_{i t}=\alpha+\beta_{1} \ln P C_{i t}+\beta_{2} \ln G D S_{i t}+\beta_{3} \ln G D P_{i t}+\beta_{4} \ln F D I_{i t}+\varepsilon_{i t}
$$

In this model, $\beta$ is the coefficient of all the variables, i represents the developing countries from which the data has been collected, $t$ represents the time period of data collection and finally $\varepsilon$ means the error term. 


\subsection{Estimation Procedure}

The first step of the estimation procedure was to carry out the cross sectional dependency test that might be present between the variables. If this test is not carried out and the cross sectional dependence is not checked, the results obtained from the study will not be very reliable and accurate (Paramati, Mo, \& Gupta, 2017). This test is carried out because it is a common assumption there are various aspects through which the countries from which data is collected are connected to each other such as trade agreements, financial issues etc. If the cross sectional dependence (CSD) is found out among the variables, this would lead to the fact that normal or first generation unit root tests cannot be used in order to estimate the stationary properties of the data. This is because of the reason that these tests do not have the capability to control the issue of cross dependence (Liu, 2013). In order to resolve this issue, the researcher has applied cross sectional augmented Dickey Fuller CADF unit root test and cross sectional ImPesaran Shin CIPS tests in the current study. The null hypothesis of these tests is that there is unit root in the collected data and it is non stationary (Pesaran, 2007). On the contrary, the alternate hypothesis points towards the fact that there is no unit root and the data is found stationary. The following equation can be used in this regard,

$$
\Delta y_{i, t}=a_{i}+\rho y_{i, t}-1+\sum_{J=1}^{p i} a_{J} \Delta y_{i, t-J}+\varepsilon_{i, t}
$$

After unit root test, the research wanted to find out the cointegrated relationships between the variables of the study. Different tests such as Kao, Pedroni, Johansen cointegration tests are generally used for this purpose but these tests do not have the capability to address the issue of CSD therefore the researcher has used Wasterlund cointegration test which has the capability to resolve the issue of CSD (Westerlund, 2007). The null hypothesis of this test is that there is no cointegration among the variables while the alternate hypothesis has the opposite assumption.

In order to find out the long run elasticity of the variable of the study, generally some first generation tests are used but these tests do not have the capability to address the issue of CSD. Therefore, in the current research, the researcher has employed CUP BC and CUP FM because these techniques have the ability to resolve the issues of CSD as well as the endogeneity issues (Ulucak \& Bilgili, 2018). In addition, the reason to use these techniques is that the sample collected by the researcher is of sufficient size and power. Moreover, these techniques also have the ability to provide accurate results even when the order of integration of the variables is mixed. The following equation can be used for this purpose;

$$
\left(\widehat{\beta_{C U P}}, \widehat{F_{C U P}}\right)=\operatorname{argmin} \frac{1}{n T^{2}} \sum_{i=1}^{n}\left(y_{i}-x_{i} \beta\right) M_{F}\left(y_{i}-x_{i} \beta\right)
$$

Although the aforementioned techniques provide information about the long run relationships among the variables but they do not provide information about the casual relationships. Keeping in view the CSD of the variables, the traditional methods of casualty can be employed such as Dumitrescu and Hurlin casualty test. This test also has the ability to consider heterogeneity in the collected panel data (Dumitrescu \& Hurlin, 2012).

\section{Findings of the Study}

The results of correlation test have been reported in the correlation matrix presented in the Table 1. According to the matrix, it is quite clear that the dimensions of financial development i.e. private credit and gross domestic savings have positive association with the economic globalization. In addition, the matrix also shows that there is no correlation issue among the variables of the study.

Table-2. Correlation Matrix

\begin{tabular}{c|c|c|c|c|c}
\hline Variables & PC & GDS & EG & GDP & FDI \\
\hline PC & 1 & & & & \\
\hline GDS & 0.746 & 1 & & & \\
\hline EG & 0.301 & 0.565 & 1 & & \\
\hline GDP & 0.798 & 0.776 & 0.433 & 1 & \\
\hline FDI & 0.401 & 0.513 & 0.502 & 0.634 & 1 \\
\hline
\end{tabular}

The next test to be discussed here is cross sectional dependence test and the results have been reported effectively in the Table 2. According to these results, the researcher has made it evident that all the variables have rejected the null hypothesis of no CSD with one percent significance value. These results make it clear that there is cross sectional dependence issue among the variables of the study. 
Table-3. CSD Test.

\begin{tabular}{c|c|c}
\hline Variables & CD Test & Corr. \\
\hline $\ln \mathrm{PC}$ & $13.45^{* * *}$ & 0.603 \\
\hline $\ln \mathrm{GDS}$ & $42.62^{* * *}$ & 0.612 \\
\hline $\ln \mathrm{EG}$ & $64.32^{* * *}$ & 0.810 \\
\hline $\ln \mathrm{GDP}$ & $38.43^{* * *}$ & 0.434 \\
\hline $\ln \mathrm{FDI}$ & $50.91^{* * *}$ & 0.601 \\
\hline Note: $*$ for significant $10^{*} * *$ for significant $5 \% * * *$ for significant $1 \%$
\end{tabular}

Note: * for significant $10 \%$, ** for significant $5 \%$, *** for significant $1 \%$

After the confirmation the results of correlation and cross-sectional dependence, the researcher had applied the CADF and CIPS unit root tests in order to study the stationary characteristics of the collected data. Verdicts of these two tests have been presented in the Table 3. It can be seen in the results of CADF that in level series, only gross domestic savings and GDP have rejected the null hypothesis and the remaining variables have accepted the null hypothesis. On the other hand, in case of first difference all the variables have found rejecting the null hypothesis of unit root and non-stationary. In the exact similar way, in case of CIPS, the level series indicates that only economic globalization and GDP have rejected the null hypothesis, but the first difference series indicates that all the variables have rejected the null hypothesis. In a nutshell, it can be stated that in level series the data is non-stationary and when first difference is applied on the collected data, it becomes stationary.

Table-4. Unit root test.

\begin{tabular}{c|c|c|c|c}
\hline \multirow{2}{*}{ Variables } & \multicolumn{2}{|c|}{ CADF Test } & \multicolumn{2}{c}{ CIPS Test } \\
\cline { 2 - 5 } & Level & $\mathbf{1}^{\text {st }}$ Difference & Level & $\mathbf{1}^{\text {st }}$ Difference \\
\hline PC & -4.7364 & $-9.8621^{* * * *}$ & -3.6041 & $-12.2723^{* * *}$ \\
\hline GDS & $-3.2644^{* *}$ & $-8.4183^{* * *}$ & -2.2328 & $-8.4642^{* * *}$ \\
\hline EG & -6.2049 & $-14.5245^{* * *}$ & $-4.1093^{* *}$ & $-12.7032^{* * *}$ \\
\hline GDP & $-5.6382^{* *}$ & $-8.3752^{* * *}$ & $-5.0238^{* *}$ & $-13.6054^{* * *}$ \\
\hline FDI & -6.5042 & $-10.2754^{* * *}$ & -4.5005 & $-11.7223^{* * *}$ \\
\hline Note: * for significant $10 \%, * *$ for significant $5 \%, * * *$ for significant $1 \%$.
\end{tabular}

The results of the next applied test i.e. Wasterlund Cointegration test have been reported in the Table 4. It can be seen in the table that $\mathrm{Gt}, \mathrm{Ga}$ and $\mathrm{Pt}$ statistics have rejected the zero hypothesis of no cointegration. This is because of the fact that $p$ values in these cases are less than 0.05 which confirm this result. It confirms that there are cointegrated relationships between the variables. In other words, the variables i.e. private credit, gross domestic savings, economic globalization, GDP and foreign direct investment are related to each other.

\begin{tabular}{c|c|c|c}
\multicolumn{5}{c}{ Table-5.Wasterlund Cointegration Test. } \\
\hline Statistics & Value & Z Value & P Value \\
\hline $\mathrm{Gt}$ & $-2.647^{*} *$ & -3.272 & 0.021 \\
\hline $\mathrm{Ga}$ & $-5.803^{*} *$ & 0.765 & 0.032 \\
\hline $\mathrm{Pt}$ & $-7.423^{*} *$ & -2.885 & 0.044 \\
\hline $\mathrm{Pa}$ & -7.783 & -1.232 & 0.422 \\
\hline \multicolumn{4}{l}{ Note: $*$ for significant $10 \%,{ }^{* *}$ for significant $5 \%,{ }^{*} *$ for significant $1 \%}$.
\end{tabular}

The results of long run estimation for both CUP FM and CUP BC have been presented in the Table 5. In this regard, the results indicate that private credit has positive impact on the EG in case of both CUP FM and CUP BC and with one unit increase in private credit, the economic globalization will be enhanced by $22.3 \%$ and $42.1 \%$ respectively. In the similar way, the impact of the other dimension of fd i.e. gross domestic savings has favorable impact on EG in case of both CUP FM and CUP BC and with one unit increase in GDS, the economic globalization will be enhanced by $36.4 \%$ and $22.1 \%$ respectively. As far as the control variable is concerned, GDP has significant and positive impact on the economic globalization in case of both CUP FM and CUP BC and with one unit increase in private credit, the economic globalization will be enhanced by $25.4 \%$ and $31.4 \%$ respectively. In the last, the impact of the other control variable, FDI also has significant and positive impact on the economic globalization in case of both CUP FM and CUP BC and with one unit increase in private credit, the EG will be enhanced by $14.3 \%$ and $11.7 \%$ respectively.

In the last, the researcher has checked the casual relationships between the variables of the study by applying Granger Casualty Test, the results of which have been presented in Table 6. According to these results, bidirectional casualty is running between private credit and FDI and also between gross domestic savings and GDP. On the other hand, gross domestic saving granger causes private credit as well. Similarly, GDP is granger causing private credit and FDI in unidirectional way. Lastly, FDI is having unidirectional casual relationship towards economic globalization. 
Table-6. Long run estimation.

\begin{tabular}{c|c|c|c|c}
\hline \multirow{2}{*}{ Variables } & \multicolumn{2}{|c}{ CUP FM } & \multicolumn{2}{c}{ CUP BC } \\
\cline { 2 - 5 } & Coefficients & T statistics & Coefficients & T statistics \\
\hline $\ln \mathrm{PC}$ & $0.222^{* * *}$ & 3.8346 & $0.401^{* *}$ & 3.4246 \\
\hline $\ln \mathrm{GDS}$ & $0.361^{* * *}$ & 8.5640 & $0.231^{* *}$ & 8.9642 \\
\hline $\ln \mathrm{GDP}$ & $0.204^{* *}$ & 11.8644 & $0.324^{* * *}$ & 6.5243 \\
\hline $\ln \mathrm{FDI}$ & $0.142^{*} * *$ & 16.5343 & $0.127^{* * *}$ & 13.6532 \\
\hline
\end{tabular}

Table-7. Granger casualty test.

\begin{tabular}{c|c|c|c|c|c}
\hline Variables & PC & GDS & EG & GDP & FDI \\
\hline PC & - & .051 & .122 & .016 & $.102^{*}$ \\
\hline GDS & $.303^{* *}$ & - & .013 & $.119^{*}$ & .052 \\
\hline EG & .054 & .033 & - & .065 & .011 \\
\hline GDP & $.031^{*}$ & $.026^{*}$ & .033 & - & $.058^{*}$ \\
\hline FDI & $.202^{*} *$ & .012 & $.122^{*}$ & .002 & - \\
\hline
\end{tabular}

\section{Discussion}

This study was aimed at finding the influence of FD on the EG in the selected developing countries along with the two control variables i.e. GDP and FDI, selected by the researcher in context of this study. The data was collected from the selected countries and was subjected to different techniques and tools such as URT cross sectional dependence and correlation test, Granger Casualty test etc. and the desired results were obtained. The basic result of the current study is that credit to PS has significant and direct impact on the EG as the private companies play an important role in the economy of any country. In addition, in context of globalization, the role of private sector is also significant as it provides innovate and new technology that might be exported to the other countries and business ideas as well. If these companies are provided credit on easy terms and conditions, it might result in the increase in economic globalization. This result can be confirmed from the past studies (Law, Azman-Saini, \& Tan, 2014; Prokopowicz, 2016). The next result was that the gross domestic saving has significant impact on the economic globalization. The reason behind this might be that if the savings are increased domestically and are invested in technology, research and development and innovation, it might assist in starting businesses and companies in the other countries leading towards economic globalization. This result is also in accordance with the similar past studies (Nosova, 2017). Moreover, the impact of the control variable GDP also has found to cast positive and significant influence on the EG. The reason behind this result is that when the GDP of the country increases, the government might invest it in different businesses and start them in the foreign countries. In addition, the governments might also invest in the foreign businesses leading ultimately towards economic globalization. This outcome is significant with the earlier studies by the other researchers (Song, Li, \& Cao, 2018). In the last, the impact of the other control variable FDI has also been found as significant on the economic globalization. As FDI involves the investment from the foreign countries and regions and it results in enhancement of economic globalization in. These results are having consistency with the past literature (Asongu \& De Moor, 2017).

\section{Conclusion}

The results of the current study have indicated that the both dimensions of FD i.e. gross domestic savings and private credit has direct impact on EG. In addition, the impact of the two control variables i.e. GDP and FDI has also been found as significant and positive. Thus in the line of these findings, it can be concluded that the developing kingdoms must improve the performance of their private sectors by giving them credits on easy terms and conditions and they must also consider increasing their savings and spending them rationally on innovative projects that might help them in increasing the economic globalization. They must also give attention to the overall economic condition of the country so that the FDI can be attracted from different regions of the world especially the developed countries that will give rise to the economic globalization in these countries.

\section{Implications}

The most important implication of the current study is the practical implication and it is for the governments and the private sector of the developing countries that have been selected by the researcher in the current study. The governments and the private sectors of these countries might acquire assistance from the current study in order to improve the performance of their private sectors by giving them credits on easy terms and conditions and to consider increasing their savings and spending them rationally on innovative projects that might help them in increasing the economic globalization. In addition, this study might also be 
useful for the researchers as it might provide information about the relationship between FD and EG in developing countries.

\section{Limitations}

These researchers might also consider improving the study by bringing innovation and novelty in their researches. In this regard, they are recommended to enhance the sample size of the study. They might also consider some other group of countries other than the developing countries for the same study context. The other dimensions of globalization may also be focused in the future studies such as political globalization, cultural globalization etc.

\section{References}

Asongu, S. A., \& De Moor, L. (2017). Financial globalisation dynamic thresholds for financial development: Evidence from Africa. The European Journal of Development Research, 29(1), 192-212.Available at: https://doi.org/10.1057/ejdr.2016.10.

Barrow, C. W., \& Keck, M. (2017). Globalization theory and state theory: The false antinomy. Studies in Political Economy, 98(2), 177-196.Available at: https://doi.org/10.1080/07078552.2017.1342999.

Chin, G. T., \& Gallagher, K. P. (2019). Coordinated credit spaces: The globalization of Chinese development finance. Development and Change, 5O(1), 245-274.Available at: https://doi.org/10.1111/dech.12470.

Chorn, S., \& Siek, D. (2017). Impact of foreign capital inflows on economic growth of developing countries. Journal of Finance and Economics, 5(3), 128-135.

Coulibaly, S. K., Erbao, C., \& Mekongcho, T. M. (2018). Economic globalization, entrepreneurship, and development. Technological Forecasting and Social Change, 127, 271-280.

Dumitrescu, E.-I., \& Hurlin, C. (2012). Testing for granger non-causality in heterogeneous panels. Economic Modelling, 29(4), 1450-1460.Available at: https://doi.org/10.1016/j.econmod.2012.02.014.

Eppinger, P., \& Potrafke, N. (2016). Did globalisation influence credit market deregulation? The World Economy, 39(3), 426-443.Available at: https://doi.org/10.1111/twec.12282.

Ghosh, A. (2017). How does banking sector globalization affect economic growth? International Review of Economics $\bigotimes^{\circ}$ Finance, 48(C), 83-97.Available at: https://doi.org/10.1016/j.iref.2016.11.011.

Gözgör, G., \& Can, M. (2017). Causal linkages among the product diversification of exports, economic globalization and economic growth. Review of Development Economics, 21(3), 888-908.Available at: https://doi.org/10.1111/rode.12301.

Hay, C. (2016). International relations theory and globalization.

Hossain, M. S., Kibria, M. G., \& Islam, M. S. (2018). Does globalization affect the economic growth of Bangladesh? An econometric analysis. Asian Economic and Financial Review, 8(12), 1384-1393.

Jha, P., \& Gozgor, G. (2019). Globalization and taxation: Theory and evidence. European Journal of Political Economy, 59(C), 296-315.

Katircioğlu, S., \& Zabolotnov, A. (2020). Role of financial development in economic globalization: Evidence from global panel. Applied Economics Letters, 27(5), 371-377.Available at: https://doi.org/10.1080/13504851.2019.1616058

Law, S. H., Azman-Saini, W., \& Tan, H. B. (2014). Economic globalization and financial development in East Asia: A panel cointegration and causality analysis. Emerging Markets Finance and Trade, 50(1), 210-225.Available at: https://doi.org/10.2753/ree1540-496x500112.

Liu, Y. (2013). Energy production and regional economic growth in China: A more comprehensive analysis using a panel model. Energies, 6(3), 1409-1420.Available at: https://doi.org/10.3390/en6031409.

Nosova, O. (2017). The impact of globalization on financial institutions' development. Europe Regions, 30, 99-1 19.Available at: https://doi.org/10.18276/er.2017.30-07.

Paramati, S. R., Mo, D., \& Gupta, R. (2017). The effects of stock market growth and renewable energy use on $\mathrm{CO} 2$ emissions: Evidence from G20 countries. Energy Economics, 66, 360-371.Available at: https://doi.org/10.1016/j.eneco.2017.06.025

Pesaran, M. H. (2007). A simple panel unit root test in the presence of cross-section dependence. Journal of Applied Econometrics, 22(2), 265-312.Available at: https://doi.org/10.1002/jae.951.

Phong, L. H. (2019). Globalization, financial development, and environmental degradation in the presence of environmental kuznets curve: Evidence from ASEAN-5 countries. International Journal of Energy Economics and Policy, 9(2), 40-50.

Prokopowicz, D. (2016). The importance of economic globalization in the context of the development of the financial system in Poland. International Journal of Nerw Economics and Social Sciences, 4, 7-17.Available at: https://doi.org/10.5604/01.3001.0010.3862.

Sehrawat, M., \& Giri, A. (2019). Globalization, role of institutions and economic performance in Indian economy: Empirical evidence. Journal of Financial Economic Policy, 11 (1), 82-100.Available at: https://doi.org/10.1108/jfep-03-20180052.

Sethi, P., Chakrabarti, D., \& Bhattacharjee, S. (2020). Globalization, financial development and economic growth: Perils on the environmental sustainability of an emerging economy. Journal of Policy Modeling, 42(3), 520-535.Available at: https://doi.org/10.1016/j.jpolmod.2020.01.007.

Shahbaz, M., Mallick, H., Mahalik, M. K., \& Hammoudeh, S. (2018). Is globalization detrimental to financial development? Further evidence from a very large emerging economy with significant orientation towards policies. Applied Economics, 50(6), 574-595.Available at: https://doi.org/10.1080/00036846.2017.1324615.

Song, H., Li, G., \& Cao, Z. (2018). Tourism and economic globalization: An emerging research agenda. Journal of Travel Research, 57(8), 999-1011.Available at: https://doi.org/10.1177/0047287517734943. 
Tariq, M., Xu, Y., Muhammad, F., \& Alam, K. M. (2019). The dirty energy dilemma via financial development and economic globalization in Pakistan: New evidence from asymmetric dynamic effects. Environmental Science and Pollution Research, 26(25), 25500-25512.Available at: https://doi.org/10.1007/s 11356-019-05752-4.

Ulucak, R., \& Bilgili, F. (2018). A reinvestigation of EKC model by ecological footprint measurement for high, middle and low income countries. Journal of Cleaner Production, 188, 144-157.Available at: https://doi.org/10.1016/j.jclepro.2018.03.191.

Wang, L., Vo, X. V., Shahbaz, M., \& Ak, A. (2020). Globalization and carbon emissions: Is there any role of agriculture value-added, financial development, and natural resource rent in the aftermath of $\operatorname{COP} 21$ ? Journal of Environmental Management, 268, 110712.Available at: https://doi.org/10.1016/j.jenvman.2020.110712.

Westerlund, J. (2007). Testing for error correction in panel data. Oxford Bulletin of Economics and Statistics, 69(6), 709748.Available at: https://doi.org/10.1111/j.1468-0084.2007.00477.x.

Zaidi, S. A. H., Zafar, M. W., Shahbaz, M., \& Hou, F. (2019). Dynamic linkages between globalization, financial development and carbon emissions: Evidence from Asia pacific economic cooperation countries. Journal of Cleaner Production, 228, 533-543.Available at: https://doi.org/10.1016/j.jclepro.2019.04.210. 